\title{
$\square$
}

\section{A Primer on Social Security Systems and Reforms}

\author{
Craig P. Aubuchon, Juan C. Conesa, and Carlos Garriga
}

\begin{abstract}
This article reviews the characteristics of different social security systems. Many configurations arise depending on the nature of a system's funding and determination of benefits. Many reforms propose changing the social security systems. The authors focus their analysis of the transition from a pay-as-you-go to a fully funded system. They argue that the key component of any reform is the treatment of the implicit liabilities of a country's social security system. The welfare gains accruing to some cohorts as a result of such reforms usually stem from either a partial or complete default on the implicit debt of the system, and in that sense the gains imply only a redistribution of welfare across agents. In contrast, the elimination of existing distortions in social security financing can generate efficiency gains, allowing for welfare improvements for all agents. This result shifts the focus from the nature of the system itself and centers the debate on the distortions associated with social security. (JEL H2, E62, D31)
\end{abstract}

Federal Reserve Bank of St. Louis Review, January/February 2011, 93(1), pp. 19-35.

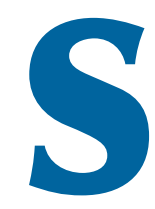

ocial security," by its simplest definition, is a contract between a government and its constituents. Under this contract, citizens provide funding to a social security system, and in exchange they receive benefits from the system during their nonworking years, generally during old age or prolonged illness (disability). The U.S. Social Security system was implemented in 1935 under President Franklin Roosevelt. This system, formally known as Old-Age, Survivors, and Disability Insurance (OASDI), is a pay-as-you-go (PAYG) system in which workers provide financing through a Social Security tax; these contributions provide benefits to the currently retired or disabled. The system requires an implicit guarantee that future generations will then provide the same support for them. In contrast, fully funded (FF) social security systems require that benefits accrue based on individual contributions paid over time. In such systems, future obligations are fully funded by earlier contributions.

Financial sustainability of the U.S. Social Security system is an important policy concern because of the aging population, particularly the baby boom cohorts. The recent recession, combined with the renewed political focus on health care and long-term health costs, has led to increased interest in the long-run financial stability of the U.S. Social Security system. While the Board of Trustees of OASDI has expressed the need for long-term reform for several years, their 2009 report described how lower gross domestic product (GDP) and fewer covered workers affect the long-term outlook (see Board of Trustees, 2009). The Board moved forward its projections for the year in which outlays will exceed revenues (2016) and the year in which

Craig P. Aubuchon was a research analyst at the Federal Reserve Bank of St. Louis. Juan C. Conesa is an associate professor in the department of economics at the Universitat Autònoma de Barcelona, Spain. Carlos Garriga is an economist at the Federal Reserve Bank of St. Louis. The authors thank Ricardo DiCecio, William Gavin, and Christopher Neely for their reviews and comments.

(C) 2011, The Federal Reserve Bank of St. Louis. The views expressed in this article are those of the author(s) and do not necessarily reflect the views of the Federal Reserve System, the Board of Governors, or the regional Federal Reserve Banks. Articles may be reprinted, reproduced, published, distributed, displayed, and transmitted in their entirety if copyright notice, author name(s), and full citation are included. Abstracts, synopses, and other derivative works may be made only with prior written permission of the Federal Reserve Bank of St. Louis. 
current trust funds will be exhausted (2037). The 2010 Trustees Summary Report concludes that these imbalances "demonstrate the need for timely and effective action. The sooner the solutions are adopted, the more varied and gradual they can be" (see Social Security and Medicare Boards of Trustees, 2010). These solutions include higher taxes, lower benefits, or a combination of both to replenish the trust fund. However, some analysts advocate a transition to an FF Social Security system.

Building on the seminal work of Auerbach and Kotlikoff (1987), several quantitative analyses simulate the transition from a PAYG to an FF system and find substantial efficiency and welfare gains in the long run. However, the gains often come at the expense of the transition generation. For example, Huang, Selahattin, and Sargent (1997) show that partial or full privatization implies large short-run welfare losses that cannot be compensated by the long-run gains. Conesa and Krueger (1999) show that in the presence of uninsurable labor income uncertainty the welfare losses of the initial cohorts are large and constitute a political barrier to potential reforms. In contrast, a large empirical literature argues that the macroeconomic effects of privatizations have been small, particularly with regard to aggregate saving rates. ${ }^{1}$

The objective of this paper is to provide a theoretical framework to illustrate the effects of reforming social security. We use a simple overlapping generations model to demonstrate when a transition from a PAYG system to an FF system can (and cannot) be welfare improving for all households in the economy. The model includes the initial generations alive at the beginning of the reform as well as future generations. We first show that a PAYG system and an FF system can be equivalent by using a simple government transfer mechanism that makes explicit the implicit debt of the PAYG system. This is nothing more than the recognition of the implicit liability of

\footnotetext{
1 Coronado (2002) finds that after the 1981 Chilean social security reform (covered in the next section), wealthy families increased aggregate savings by approximately 7 percent. In contrast, Butelman and Gallego (2000) find that low-income Chilean households increased their level of debt. Disney, Emmerson, and Smith (2003) and Granville and Mallick (2002) find no effect on aggregate household saving rates after the 1986 U.K. reforms.
}

the social security system with future generations. An immediate application of the equivalence result is that it would be straightforward to engineer a Pareto-neutral social security transition. The equivalent FF system produces the same level of welfare, household decisions (i.e., labor supply and consumption), and output. If the reform implies only the recognition of the implicit debt with no welfare effects, how can this be reconciled with the sizable welfare gains noted in the literature? In most simulations of reforms, pensions and social security contributions are eliminated over time in some arbitrary way. Generally, most such exercises imply some partial or complete default on promises (equivalent to a default on the implicit debt of social security), which was the root of the large welfare losses of the transition cohorts. When the government is allowed to default on the implicit liabilities, the welfare of either existing or future cohorts-but not bothcan be improved. Therefore, the post-reform welfare gains by some individuals are the result of not honoring these liabilities and not of the reform itself. The equivalence result shows that when the implicit debt is honored, there is no room for welfare improvements in the event of a privatization.

Because intergenerational redistribution alone cannot generate Pareto improvements in a dynamically efficient economy, these improvements are possible if and only if there are distortions in social security financing or in the tax system. In such circumstances, the presence of additional distortions, not the reform itself, is the key to any welfare improvement. Therefore, sizable welfare gains are possible when substantial economic distortions occur, but welfare gains are negligible if the social security contributions and the tax code are close to optimal. These results might explain why the empirical literature has found small macroeconomic effects resulting from many reforms in actual economies. Our exercise suggests that no macroeconomic and welfare effects should be expected unless distortions are minimized or eliminated. Successful reform requires some substance, not just relabeling of government debt. 


\section{Table 1}

\section{Configurations of Social Security Systems}

\begin{tabular}{ll} 
Type of plan & \multicolumn{1}{c}{ Funded } \\
\hline Defined benefit & $\begin{array}{l}\text { Traditional employer pe } \\
\text { (example: Switzerland) }\end{array}$ \\
& U.S. Roth IRA or 401(k) \\
Defined contribution & Chile \\
& Latin America \\
& Australia \\
& United Kingdom
\end{tabular}

Notional defined contribution

Italy

Sweden

\section{Unfunded}

United States

Australia

United Kingdom

\section{OVERVIEW OF SOCIAL SECURITY SYSTEMS}

Not all social security systems are designed the same. Obviously, different countries have defined their social security contracts according to the principles that shape their cultures and economies. In general, there are four broad types of social security systems. These systems combine two elements. First, a system can either be unfunded (such as a PAYG system) or FF (based on accumulated assets). Second, a system can provide payments based on either defined benefits or defined contributions. Note that an FF system is not the same as a privatized system. An FF system is simply a model for savings and usually represents a switch from a defined-benefit to a defined-contribution system. ${ }^{2}$ Diamond (1996) states, "I think that the distinction between contribution and benefit base is more illuminating than the distinction between privatization and government-run systems, for various pieces of either type of system can be privatized” (p. 75). Table 1 summarizes the different configurations of social security systems.

In 1994, the World Bank released a comprehensive review, Averting the Old Age Crisis:

2 Diamond (2004) gives an alternative definition of "defined contribution" and notes that the heart of a defined-contribution system is the fact that the risk to future outcomes is on the side of benefits, which are a function of the realized returns on funded contributions. This is in contrast to the risk of an unfunded system, which generally falls on future taxes.
Policies to Protect the Old and Promote Growth, and advocated a three-pillar model to social security. The three pillars have been broadly interpreted as the World Bank model and consist of (i) a publicly managed, unfunded, defined-benefit pillar; (ii) a privately managed, funded, definedcontribution pillar; and (iii) a voluntary savings pillar. Orszag and Stiglitz (1999) point out that the World Bank did not explicitly argue for a privately managed second pillar but that many scholars have interpreted it as such. ${ }^{3}$ This threepillar approach should sound familiar to most Americans: Those who participate in Social Security through payroll taxes, save through a 401(k) plan or individual retirement account (IRA), and manage their own private assets engage in the three pillars advocated by the World Bank.

Many workers are inadequately prepared for retirement because they do not participate in the voluntary second and third pillars. According to the 2007 Survey of Consumer Finances (SCF), only 60.9 percent of U.S. households 55 to 64 years of age have a retirement account outside Social Security and only 41.6 percent of households 35 years of age and younger have a retirement account in place (see Federal Reserve Board,

3 For a recent example, see the February 2009 testimony of Alicia Munnell and Peter Drucker before the U.S. House of Representatives; they articulate that a strong second pillar of an FF definedcontribution plan will help diversify risk and improve retirement portfolios. 
2007). ${ }^{4}$ Across all ages, the $S C F$ finds that 57.7 percent of families have some rights to a definedbenefit pension or account plan through a current or past employer. Thus, for any combination of reasons, a large majority of families have chosen not to participate in retirement savings outside Social Security, even though Social Security is designed to replace only 40 percent of preretirement income for the average worker retiring in 2007 (Social Security Administration, 2008). The differences across systems (see Table 1) are explained next.

\section{Funded Defined-Contribution System}

Current private pensions, such as $401(\mathrm{k})$ plans and Roth IRAs, are a type of funded definedcontribution system. Workers contribute a percentage of their salaries during working years, often with a matching employer contribution up to an established limit. Workers are free to choose the investment of their funds and are eligible to withdraw their savings during their retirement years, with a total sum equal to their defined contribution plus investment earnings. Chile's social security reform in 1981 remains the bestknown international example of an FF definedcontribution system; Diamond (1996) presents a survey of the literature examining the pros and cons of this model. Under the Chilean system, all workers are required to contribute 10 percent of their salary into a savings plan of their choice, which is administered and regulated by the Administradora de Fondos de Pensiones. As in the United States, eligibility for retirement is based on age and early retirement is available to those with sufficient accumulated savings. At retirement, workers can choose monthly withdrawals or purchase an annuity. Furthermore, workers are guaranteed a minimum pension paid from the general revenue fund. In Chile, the benefits of such a system include reduced exposure to politi-

\footnotetext{
4 The 2007 SCF does not include annuities in this measure and notes that some "families may have used funds from previous employment to purchase an annuity at retirement" (p. A23). The survey also notes that among older age brackets (55 to 64 years), workers can withdraw funds from some retirement accounts as early as age $59^{1 / 2}$.
}

cal and demographic risk since retirement benefits are funded and cannot be reduced through taxes.

Several other countries, including most of Latin America, have a funded defined-contribution pillar that follows Chile's example. Valdés-Prieto (1998) presents a summary of the reforms in Peru, Colombia, Argentina, Bolivia, Mexico, El Salvador, and Uruguay. He offers five reasons why Chile's model is so successful, including low levels of private-sector corruption, little political pressure on investment options, and successful implementation of a redistributive means-tested benefit to workers not covered by the Administradora de Fondos de Pensiones.

Bateman and Piggot (1998) summarize the pension reforms in Australia and the success of its funded defined-contribution pillar, the superannuation guarantee. The Australian system operates under a model similar to Chile's with the exceptions that fund choices for each pension are governed by a board of trustees and assets and allocation are unrestricted. Australia's system is also unique in that taxes are levied at all three possible points-contributions, investment earnings, and benefits. Finally, Australia offers the choice of either a lump-sum payment or an annuity at retirement. The lump-sum payment is unique among funded defined-contribution plans; the authors point out that from a societal perspective, the policy is inefficient because individuals who spend their lump sums must then rely on the state.

The U.K. system also offers a privatized, funded defined-contribution system but a unique one, in that it allows workers to opt out of their public, unfunded defined-benefit system. Indeed, as Johnson (1998) reports, between 1988 and 1992, the United Kingdom offered an additional 2 percent "incentive" rebate to workers switching to a private pension. Thus, an unfunded future benefit is replaced with a currently funded contribution. Johnson notes that younger workers benefit more from switching and, as expected, have done so in large numbers. However, studies have also shown that many workers have opted out of an occupational pension program to join the private pension, in essence giving up any company con- 
tribution to their plans. Thus, the issue of choice has been effective for most, but some workers have made second-best choices.

\section{Funded Defined-Benefit System}

More traditional pensions, similar to those awarded to older U.S. workers during previous decades, are good examples of funded definedbenefit systems. Workers pay into the pension system, and the corporation manages how these contributions are invested. Workers then receive a defined benefit at retirement, which is usually based on years of service or some other related measure.

Switzerland currently offers a hybrid system: a funded defined-contribution system with a guaranteed return. The burden of the Swiss compulsory occupational pension scheme (overseen by a trustee board) is placed directly on individual corporations. The board chooses the pension insurance and the amount and is responsible for enrolling workers. Workers contribute 17 percent of their salary, half of which is matched by the corporation. Under these requirements, the system is purely a defined-contribution plan. However, each pension plan is required to return a minimum of 4 percent nominal interest each year. ${ }^{5}$ If a pension plan is ever underfunded, the firm or corporation must make up the difference. This legal, and explicit, guarantee on returns makes the Swiss system more of a defined-benefit plan since workers know with some certainty the value of their future annuity.

\section{Unfunded Defined-Benefit System}

A publicly operated, unfunded defined-benefit plan constitutes the first pillar of social security among most countries. These systems are often described as PAYG because current workers pay taxes to provide a benefit to the current retired generation. An individual's benefits are offered either as means-tested, such that a worker receives

\footnotetext{
5 The 4 percent rate was chosen to be slightly below the long-run return on Swiss government bonds of 4.5 percent. Hepp (1998) summarizes, "The return guarantee was deemed unambitious enough to avoid frequent funding shortfalls...but explicit enough to enhance the credibility of the system" (p. 536).
}

benefits only if they are below an income threshold or as a universal benefit given to all workers, often calculated as a percentage of the earnings average over a set number of working years. Benefits are also linked to either wage growth or price growth so that benefits stay roughly in line with the cost of living. The U.S. Social Security system is generally considered an unfunded defined-benefit system. Workers pay into the system through a tax, which is then transferred to the current retired generation in the form of a defined benefit. In the United States, the universal benefit is based on a worker's average earnings over a 35-year period, up to a certain income level. Furthermore, under the U.S. system, benefits are also provided to spouses and dependents. Diamond (2004) asserts that the unfunded nature of U.S. Social Security makes sense given the early decision to redistribute wealth and provide full benefits to the initial generation-which did not pay into the system-because the incompletefunding risk is shared across future cohorts. An upcoming section outlines the model for a PAYG system that generates this type of redistribution.

Unfunded defined-benefit plans are generally useful for a redistribution of wealth-that is, to help guarantee a minimum level of income for any worker who participates in the labor force for an agreed-upon number of years. Unfunded defined-benefit plans often favor workers with lower incomes or with noncontinuous work histories. Often, the benefit is set at a basic subsistence level and is intended to be supplemented with other retirement savings. For example, Switzerland provides a guaranteed minimum pension for its entire population, with the pension paid from general revenues. Hence, the minimum pension is independent of a worker's salary or time in the labor force. This universal benefit redistributes income to poorer workers during their retirement years.

Australia and the United Kingdom, among other countries, have a public, unfunded, definedbenefit system as a first pillar for social security. In particular, the United Kingdom has a two-tier state pension scheme. First, workers are provided a basic state pension, paid at a single flat rate that 
offers a subsistence-level income. ${ }^{6}$ Most workers are covered by occupational pension schemes, which, in one form or another, predate the state scheme; for workers not covered by the occupational program, the state also offers the State Earning Related Pension Scheme (SERPS). A unique feature of SERPS is that workers can opt out of the plan and the associated National Insurance contribution if their private pension or occupational scheme provides a guaranteed minimum pension equivalent to SERPS. In contrast, Australia offers a means-tested benefit, such that the full-rate pension is equal to 25 percent of male average earnings (40 percent for couples), but this payment is phased out as retirement income and other assets accumulated under the other two pillars increase. Similarly, Sweden offers a means-tested pension for workers with no or low income. This guaranteed pension is financed through general revenue taxes and is independent of workers' notional definedcontribution (NDC) plans.

\section{Unfunded Defined-Contribution System}

Sweden and Italy are concrete examples of countries with an unfunded defined-contribution social security system. In recent years, both countries have switched to an NDC plan. The government credits each worker for the taxes he or she and the employer contribute, and then pays a benefit equal to the worker's contributions plus a notional interest rate. Första AP-fonden (AP1, one of the pension funds managing the Swedish system) describes the Swedish income pension system as follows: "The income pension system is of the defined contribution type, meaning that the size of future pension benefits depends on

\footnotetext{
6 Johnson and Stears (1996) point out that the basic state pension is technically a defined-contribution scheme, since the pension is paid only to workers who contribute taxes during 90 percent of their working life and have Class 1 contributions on earnings of at least 52 times the weekly lower earnings limit during each working year. Thus, to qualify for the pension at age 65, a worker must have contributed for 44 years (male) or 39 years (female). However, the authors note that "there are so many special provisions that virtually everyone becomes eligible, no matter what their employment and contribution history..." (p. 1111). These exceptions include a deduction on working years for home responsibility protection, which helps guarantee coverage for stay-at-home caregivers.
}

the amount of contributions made and return on the invested capital. The income pension system is also a so-called PAYG system, which means that the pension contributions paid in every month are used to pay current income pension benefits to those who have already retired."7 However, because of the notional interest rate, Sundén (1998) states that the Swedish plan is "more similar to a defined benefit plan...since the government has to cover its pension liability through annual contributions" (p. 582).

\section{CURRENT STATE OF U.S. SOCIAL SECURITY}

The unfunded defined-benefit plan of the United States, known as OASDI, contains two separate parts. The first, and the focus of this paper, is the Old-Age and Survivors Insurance (OASI), which pays monthly benefits to retired workers and their families. The second component, Disability Insurance (DI), pays monthly benefits to disabled workers and their families. The 2009 annual report of the Board of Trustees presents the most-current picture of Social Security in the United States and notes that, in 2008, almost 35 million retired workers and their dependents and another 6 million survivors of deceased workers received benefits. An estimated 162 million workers paid Social Security and payroll taxes. Total benefits paid in 2008 were $\$ 615$ billion, and the Social Security Trust Fund collected $\$ 805$ billion, prompting the Trustees to note that "the combined OASI and DI Trust Funds are adequately financed over the next ten years" (see Board of Trustees, 2009, p. 2). However, the Trustees also state very clearly: "The financial condition of the Social Security and Medicare programs remains challenging" and that the current PAYG system "does not satisfy the short range test of financial adequacy."

These long-run problems arise as the baby boom generation begins to retire and reduces the number of covered workers per beneficiary from

\footnotetext{
7 More information on the Swedish system is available at the Första AP-fonden website (www.ap1.se/en/Our-mission/The-Swedish-pension-system/).
} 
a historical average of three workers per beneficiary to just two workers per beneficiary. As is well documented elsewhere, the Board of Trustees (2009) currently predicts that income received will exceed benefits payments in 2016. Because of the surplus accrued and interest generated on these savings, the payment of benefits will not be reduced until 2037, when the surplus is predicted to run out. At this point, the Trustees estimate that under their intermediate assumptions, payable benefits will be 76 percent of scheduled benefits and by 2038, tax income will cover 74 percent of scheduled benefits. ${ }^{8}$

The Trustees conclude that for the trust fund to remain solvent throughout the 75-year projection period and pay scheduled benefits at 100 percent, one of three things must happen under business as usual. ${ }^{9}$ First, the combined payroll tax could be immediately and permanently increased from 12.4 percent to 14.4 percent. Second, scheduled benefits could be reduced by an amount equal to an immediate and permanent reduction of 13 percent. Or third, a general revenue transfer equivalent to $\$ 5.3$ trillion in present value terms could be made to the trust fund.

These measures all imply a welfare loss of some type for workers and retirees during the 75year projection period. An important economic consideration to the Trustees' conclusions is the deadweight loss associated with an increase in the payroll tax. With a higher tax rate the government would collect more revenue unless the higher taxes distort an individual's decision on how much to work. The revenue lost because of

8 Under intermediate assumptions, the Board estimates a total fertility rate of 2 children per woman, an annual percentage change in productivity for the total U.S. economy of 1.7 percent, an unemployment rate of 5.5 percent, and an inflation rate (measured by the consumer price index) of 2.8 percent. Jeske (2003) notes that slight changes to the Board's assumptions can lead to drastic changes in the long-term forecast of Social Security. It is important to note that these changes run both ways: With slightly higher growth Social Security will face no funding problems, but with slightly lower growth Social Security will be even less likely to meet existing obligations. Jeske (2003) concludes that a PAYG system "therefore implies a substantial amount of risk, contrary to the amount that proponents of social security would admit" (p. 16).

9 The Trustees also note the impact of the 2007-09 recession on the Social Security system and the "business as usual" scenario, including raising estimates for the projected deficit and modeling lower GDP growth in the upcoming years. a decrease in the number of hours worked (say, from an individual declining overtime hours) is the deadweight loss of the tax. Feldstein and Liebman (2002) note that under standard theory, the deadweight loss of a tax system increases with the square of the marginal tax rate. Over time, the increased deadweight loss makes continued tax increases to fund a demographic shift less desirable since each subsequent tax increase results in a larger deadweight loss.

In the early 1980s, the United States faced a similar Social Security dilemma and pursued a strategy of tax increases and delayed benefits in the form of an increase in the normal retirement age (NRA). The Social Security Amendments of 1983 extended the NRA from age 65 to age 67 for the cohort of workers that turns 62 in 2022. Diamond (1996) provides a summary of the changes, noting that the law did not change the minimum age (62 years) to claim retirement benefits, nor did it extend the age to obtain benefits independent of earnings (70 years). Rather, it simply changed the level of benefits as a function of the age at which they are first claimed. With an NRA of 65, workers can receive 80 percent of their benefits starting at the minimum age, 62 . Under the new NRA of 67, workers receive only 70 percent of their scheduled benefit starting at age 62. Thus, extending the NRA by two years is the equivalent of cutting benefits by one-eighth. Diamond also notes that extending the NRA might have unintended consequences since there were no corresponding benefit cuts for early withdrawals for DI. This provides an incentive to apply for DI benefits at the earliest date. The loss from future income of working years and revenue savings from the reduced benefit represents another source of potential welfare loss.

Gramlich (1998) provides a brief overview of the recommendations from the 1994-96 Social Security Advisory Council. This group, which Gramlich chaired, offered three options to address the long-run actuarial soundness of Social Security. ${ }^{10}$ Options included

\footnotetext{
${ }^{10}$ See Pecchenino and Pollard (1998) for a formal theoretical treatment of the three proposals put forth by Gramlich (1998).
} 
- a Maintenance of Benefits plan, with minimal changes in benefit schedules or tax rates but a large portion of trust fund assets invested in equities, with the goal of a higher rate of return to restore actuarial balance;

- a Publicly Held Individual Accounts (IAs) plan to replace the defined-benefit system with a large-scale defined-contribution system, with OASDI as a weaker first pillar that provides a poverty-line flat benefit;

- a Two-Tiered System with Privately Held Individual Accounts plan, which Gramlich termed the "kind and gentle" benefit cut plan. With IAs, high-wage workers would experience slight benefit cuts and workers would be required to contribute to centrally managed investment accounts that convert to real annuities upon retirement.

The next subsection reviews some of the theoretical contributions addressing the issue of a transition from a PAYG to an FF system, hence providing a quantitative evaluation of many of the reforms discussed so far.

\section{Effects of a Transition from a Pay-as-You-Go to a Fully Funded System}

The differences between a PAYG and an FF social security system have been studied extensively in the economic literature. Here we review several recent papers that study the welfare implications of the transition. For a more comprehensive and nuanced review of the existing literature on social security reform, see Feldstein and Liebman (2002) and Diamond (2004).

Kotlikoff (1998) considers intergenerational welfare and efficiency in U.S. Social Security reform and advocates a consumption tax to finance the transition from a PAYG system to a definedcontribution personal security system. Under his model, an uncompensated welfare transition results in significant increases to capital stock (36.7 percent), aggregate labor supply (3.7 percent), output (11.2 percent), and real wages (7.1 percent) compared with the baseline model. However, this scenario leads to short-run decreases in aggregate welfare. Using a lump-sum redistribution author- ity to compensate the initial generation, Kotlikoff finds long-run efficiency and welfare gains above the baseline scenario but below the uncompensated transition. Kotlikoff concludes: "[T]he extent to which privatization results in efficiency gains depends on the ability of future generations to compensate current workers for the loss of consumption as a result of financing the transition" (p. 37). Conesa and Krueger (1999) propose an environment augmented to include uninsurable labor income risk, hence giving a PAYG social security system an additional role as a partial insurance device, and show that the transition offers similar conclusions.

Birkeland and Prescott (2007) consider an overlapping generations model with no population growth in both a PAYG system and an FF system. They compare the models under four demographic scenarios calibrated to match the current United States and a future United States with lower population growth and longer retirements. They note that the PAYG system has little or no explicit debt but does not fully maximize welfare for the society. Early in their paper, the authors challenge the notion of debt, stating "The government debt that a country owes to its citizens is not debt in the usual sense...[it] is a mechanism that facilitates intergenerational borrowing and lending, and is an integral part of a welfareimproving saving-for-retirement system" (p. 2).

Birkeland and Prescott (2007) also note that the Congressional Budget Office estimates that the current implicit guarantees of the PAYG system represent liabilities four times gross national income. These implicit guarantees represent a form of debt for the unborn generation, which lowers lifetime welfare. The authors find that with current U.S. demographic assumptions, welfare under an FF system is 9.2 percent higher than a PAYG system. The FF system has a higher explicit debt-to-gross national income ratio, and individuals work more under the FF system because workers have a higher take-home wage without a Social Security tax. ${ }^{11}$ Lifetime con-

\footnotetext{
${ }^{11}$ Their model considers a population growth rate of 1 percent, an NRA of age 65, and a 20-year retirement. Their future U.S. model considers a country with no population growth, an NRA of age 65 , and a 30-year retirement.
} 
sumption also remains higher for a future United States with an FF system, by 5.5 percent. While the authors find that aggregate welfare is better than under an FF system and note that an increase in explicit government debt is not a burden to future generations, they do not consider the welfare of the transition generation.

Similarly, Jeske (2003) considers the transition between social security systems and also finds that in the long run every generation benefits more from an FF system. In that system, individual savings are higher, which in turn increase the aggregate capital stock. The higher capital stock acts as a buffer to the economy in the event of large aggregate economic shocks, which disrupt the PAYG social security system. Jeske (2003) argues that "private savings are more desirable and affordable if both benefits and contributions [to PAYG] are lower" (p. 16). As do Birkeland and Prescott (2007), Jeske similarly acknowledges that social security reform has beneficial long-term effects but that, in the short run, "a large portion of the population will be worse off...[T]he problem of privatization is the unfunded liability to pay for current retirees" (p. 22).

Conesa and Garriga (2008) study the optimal financing of the transition from a PAYG to an FF system. By maximizing over the entire policy space and following an optimal fiscal policy approach, the authors find it is possible to finance such a transition in a Pareto-improving manner for all generations. In their model, the fiscal authority changes the labor income tax over time: first by lowering the labor income tax during the transition generation, issuing government debt to fund existing obligations, and then raising taxes over time to repay debt. Measured as equivalent variation in consumption, the authors find that in the transition from a PAYF to an FF system future newborn generations experience a welfare increase between 3 percent and 8 percent. Such a scheme allows for welfare gains for both actual and future generations, and the key aspect is the reduction of the distortions introduced by the tax system.

None of the above-mentioned papers considers the political ramifications of social security reform, nor do they address the social justice issues underlying the need for and extent of a social security contract between a government and its constituents. Our goal is to show the basic mechanisms by which a shift to an FF system can, in some cases, be welfare improving, even for the transition generation. As Orszag and Stiglitz (1999) point out, initial conditions matter and as such, it is an "issue of whether a shift to individual accounts would be socially beneficial" and not an issue of whether or not "in a tabula rasa sense, an individual account system would have been preferable to a public defined benefit system in the first place" (p. 5).

\section{A MODEL ECONOMY WITH A PAY-AS-YOU-GO SYSTEM}

We follow the framework of Samuelson (1958, 1975) and Diamond (1965) and consider the simplest scenario of a two-period overlapping generations model. Individuals work during the first period of their life and are retired during the second period. Consider the problem faced by an individual born in period $t$ (who will be retired in period $t+1$ ). During the working period, individuals provide labor, denoted as $\ell_{t}$, and are paid in return a wage rate per unit of labor, $w_{t}$. They consume some goods in the first period, $C_{1, t}$; they pay social security taxes on their wage income, denoted by the tax rate, $\tau_{t}$; and they can save for the next period, $a_{t+1}$, where savings today are assets that pay interest in the next period. Hence the budget constraint for these individuals is

(1) $c_{1, t}+a_{t+1} \leq w_{t} \ell_{t}-\tau_{t} w_{t} \ell_{t}$.

During the retirement period-which is the next period, $t+1$-individuals do not produce any goods; instead, they merely consume the principal and interest on their private savings and their pension payments. Therefore, their budget constraint is given by

$$
c_{2, t+1} \leq\left(1+r_{t+1}\right) a_{t+1}+p_{t+1}
$$

where $C_{2, t+1}$ denotes the consumption during retirement (in period $t+1$ ) of the individuals born in period $t, r_{t+1}$ denotes the interest payments collected on savings, and $p_{t+1}$ denotes the social 
security payments collected by the retired in period $t+1$.

If there is no exogenous restriction on the sign and magnitude of savings, ${ }^{12}$ both budget constraints can be combined as

$$
C_{1, t}+\frac{C_{2, t+1}}{1+r_{t+1}} \leq\left(1-\tau_{t}\right) w_{t} \ell_{t}+\frac{p_{t+1}}{1+r_{t+1}}
$$

This expression simply states that the net present value of consumption over the life cycle of individuals cannot be larger than the net present value of after-tax payments (labor income when individuals are young and pensions when old). Given this constraint, individuals would choose $\left(c_{1, t}\right.$, $\left.C_{2, t+1}, \ell_{t}\right)$ given $\left(\tau_{t}, W_{t}, p_{t+1}, r_{t+1}\right)$ and their preferences (i.e., how much they value consumption in the present with respect to consumption in the future and how much they value consumption today with respect to how much they dislike working).

Finally, in this world the government operates the social security system in a standard PAYG fashion: Social security contributions of the current working-age population finance the pension payments of the currently retired population. In particular, if there are $(1+n)$ workers per retired person (think of $n$ as a constant growth rate of population), the social security system would be balanced when

(4) $(1+n) \tau_{t} w_{t} \ell_{t}=p_{t}$.

Notice it is an unfunded system in the following sense. The individuals born in period $t$ will contribute to the system $\tau_{t} w_{t} \ell_{t}$. However, when they retire they will collect pensions $p_{t+1}=$ $(1+n) \tau_{t+1} w_{t+1} \ell_{t+1}$ that are not related to their own past contributions.

\section{A FULLY FUNDED SYSTEM}

An alternative to the implicit guarantee of the PAYG structure is an FF system of social security. Under our previous notation, an FF system is a defined-contribution plan similar to a $401(\mathrm{k})$

\footnotetext{
${ }^{12}$ The presence, for example, of borrowing constraints might com-
} plicate the analysis. program. ${ }^{13}$ In the model, workers save throughout their lifetimes. Whether this savings program is mandatory is irrelevant, since workers could also save (or borrow) privately if they chose to do so. Hence, given an optimal consumption allocation if the government increases compulsory savings, individuals would respond by decreasing their private savings by the same amount.

This can be easily seen by consolidating the budget constraints as follows:

$$
c_{1, t}+a_{t+1}+a_{t+1}^{m} \leq w_{t} \ell_{t}
$$

where $a_{t+1}^{m}=\tau_{t} w_{t} \ell_{t}$ denotes mandatory contributions to an IRA, computed as a fraction of current labor income. These contributions are then capitalized at the market rate of return and constitute the funding of the future retirement pension.

Hence, next period's budget constraint will include a pension, denoted

$$
c_{2, t+1} \leq\left(1+r_{t+1}\right) a_{t+1}+p_{t+1}
$$

where now $p_{t+1}=\left(1+r_{t+1}\right) a_{t+1}^{m}$ and therefore the pensions are funded by defined contributions.

Notice, though, that the net present value budget constraint is

$$
C_{1, t}+\frac{C_{2, t+1}}{1+r_{t+1}} \leq\left(1-\tau_{t}\right) w_{t} \ell_{t}+\frac{p_{t+1}}{1+r_{t+1}}=w_{t} \ell_{t} .
$$

In other words, whether savings are compulsory does not matter; in the end, the net present value of consumption is independent of the level of compulsory contributions to social security. Effectively, then, in this simple model environment an $\mathrm{FF}$ system is equivalent to private savings.

\section{COMPARISON OF THE TWO SOCIAL SECURITY SYSTEMS}

We now compare the two social security systems. For simplicity, we consider a stationary

\footnotetext{
13 It is important to make the distinction that it is not a necessary condition for FF system funds to be invested in equities. As Orszag and Stiglitz (1999) state, “...prefunding and privatization are distinct concepts, and conflating them confuses rather than informs the debate" (p. 9). Indeed, an FF system could be fully invested in government securities, with low risk and lower (but sometimes guaranteed) returns.
} 
world where social security contributions are constant over time, $\tau_{t+1}=\tau_{t}$; wages grow at some constant rate $g$ - that is, $w_{t+1}=(1+g) w_{t}$; and hours worked by each generation of workers are also constant, $\ell_{t+1}=\ell_{t}$.

Under this scenario, the PAYG social security pensions are given by

$$
p_{t+1}=(1+n) \tau_{t+1} w_{t+1} \ell_{t+1}=(1+n)(1+g) \tau_{t} w_{t} \ell_{t}
$$

and therefore the return of a PAYG social security system is equal to $(1+n)(1+g)$. Clearly, if $\left(1+r_{t+1}\right)>(1+n)(1+g)$, then each individual born in this stationary world will benefit more from a funded system, since the right-hand side of equation (7) is larger than the right-hand side of equation (3).

Usually both empirical data and economic theory tend to confirm that, on average, the return on private investment is larger than the growth rate of a stationary economy, $(1+n)(1+g)$. Notice that a systematic violation of this condition would imply that an economy is inefficiently overaccumulating capital (see Samuelson, 1975).

Clearly, if the return on private investment is larger than the growth rate of the economy, one would fare better born in a world with an FF system than a PAYG system. Nevertheless, as previously discussed, this is the correct answer to the wrong question. The relevant issue relates to the following question: Given that the current world has a PAYG social security system, is anything gained by switching to an FF system? Answering this question requires consideration of the events that occur during the transition, which in our theoretical model exists for just one period.

\section{TRANSITION BETWEEN SOCIAL SECURITY SYSTEMS}

\section{Transition I: Default on the Currently Retired}

Let us consider the scenario in which our economy is operating under a PAYG structure. Workers in this period contribute to the social security fund by paying a social security tax, under the assumed social contract that they will in turn receive a pension benefit when they retire during the next period. Their pension benefit will then be paid by the young generation of the next period, and so on.

Consider we are now in period $T$. Imagine that the government decides to switch immediately to a funded system during this period without honoring the implicit debt of the current retirees (the workers of the previous period), that is, $p_{T}=0$. The current old generation would incur a welfare loss equal to the sum of the pension obligations to the current retirees. If private savings earn a higher return than the implicit return of the social security system, then the generation working in period $T$ is better off (as are all subsequent generations). However, the contributions of the current workers are invested to finance their own future pensions, $a_{T+1}^{m}=\tau_{t} w_{t} \ell_{t}$. Effectively, the government has defaulted on its obligations to the currently retired. With this transition scheme the initial cohorts of retired individuals (or those close to retirement) bear the cost at the expense of current young and future generations.

\section{Transition II: Default on Future Generations}

Consider now that we decide to keep the promise to the currently retired, and as such, we still need to pay their pensions. We finance these pensions by issuing debt that must be repaid during the next period. The government budget constraint is now $B_{T+1}=p_{T}$ and the currently young are the only ones who absorb the new debt (in a closed economy) and their budget constraint becomes

(9) $c_{1, T}+a_{T+1}+\frac{B_{T+1}}{1+n} \leq w_{T} \ell_{T}$.

Notice than per capita debt of the young must be

(10) $\frac{B_{T+1}}{1+n}=\frac{p_{T}}{1+n}=\frac{(1+n) \tau_{T} w_{T} \ell_{T}}{1+n}=\tau_{T} W_{T} \ell_{T}$.

Clearly, the per capita debt of the young now is equal to the social security contributions under the original PAYG system. In the next period, the budget constraint of the retired will be 


$$
\begin{aligned}
& C_{2, T+1} \leq\left(1+r_{T+1}\right) s_{T+1}+\left(1+r_{T+1}\right) \frac{B_{T+1}}{1+n} \\
& =\left(1+r_{T+1}\right) s_{T+1}+\left(1+r_{T+1}\right) \tau_{T} w_{T} \ell_{T} .
\end{aligned}
$$

Since the rate of return on private savings (or in government debt) is larger, the transition cohort will benefit more than it would with the PAYG social security system.

However, future generations will experience a welfare loss, which can be seen by examining the budget constraint of the workers born in period $T+1$ :

$$
c_{1, T+1}+a_{T+2}+\frac{B_{T+2}}{1+n} \leq w_{T+1} \ell_{T+1}-t_{T+1} .
$$

These households will absorb the outstanding debt and will have to pay taxes, denoted by $t_{T+1}$. The reason can be seen from the government budget constraint:

$$
B_{T+2}+T_{T+1}=\left(1+r_{T+1}\right) B_{T+1},
$$

where total taxes collected equal the taxes per worker multiplied by the number of workers; that is, $T_{T+1}=(1+n) t_{T+1}$. Notice that in the absence of this new tax, the outstanding debt would explode to infinity, creating a Ponzi scheme that cannot be in equilibrium.

To maintain a constant level of debt, $B_{T+2}=$ $B_{T+1}$, the new tax should be enough to cover the interest payments on the initial debt issued:

$$
\begin{aligned}
& T_{T+1}=r_{T+1} B_{T+1} \\
& (1+n) t_{T+1}=r_{T+1} p_{T} .
\end{aligned}
$$

Hence households now must pay more in net present value to the tax authority than under the PAYG framework:

NOW: $\quad c_{1, T+1}+\frac{C_{2, T+2}}{1+r_{T+2}} \leq w_{T+1} \ell_{T+1}-t_{T+1}$

PAYG: $\quad c_{1, T+1}+\frac{C_{2, T+2}}{1+r_{T+2}} \leq w_{T+1} \ell_{T+1}-\tau_{T+1} w_{T+1} \ell_{T+1}+\frac{p_{T+2}}{1+r_{T+2}}$.

Notice that taxes paid now equal the interest payments on the government debt initially issued:

(16) $t=\frac{r p}{1+n}$.
In the PAYG regime, total taxes net of discounted pensions paid by households are

$$
\tau w \ell-\frac{p}{1+r}=\frac{p}{(1+n)(1+g)}-\frac{p}{1+r}
$$

where the equality comes from using expression (8).

Simple algebra shows that expression (16) is larger than expression (17) and, as such, all future generations now fare worse than under the original PAYG system.

\section{Welfare-Neutral Transition: No-Default Case}

We now consider an economy that honors the implicit debt of the PAYG system but does not benefit one generation at the expense of others, as was the case in the previous two examples. We follow the approach of Conesa and Garriga (2008) and allow the government to issue recognition bonds equal to the value of the government's implicit pension obligations to current workers. ${ }^{14}$

The no-default plan could proceed as follows: Since current workers are still paying their social security contributions (to honor the benefits of the current retired generation), the government will issue these workers a direct monetary transfer financed by government debt (equivalently, recognition bonds could be issued) equal to the net present value of their (lost) pension in the next period. The transfer received by the current workers is then equal to $p_{T+1} /\left(1+r_{T+1}\right)$. By construction, current workers are indifferent between this arrangement and the previous PAYG system.

The budget constraints of the transition generation are now defined as

$$
\begin{aligned}
& c_{1, T}+a_{T+1}+b_{T+1} \leq w_{T} \ell_{T}-\tau_{T} w_{T} \ell_{T}+t_{T} \\
& c_{2, T+1} \leq\left(1+r_{T+1}\right) a_{T+1}+\left(1+r_{T+1}\right) b_{T+1} .
\end{aligned}
$$

Notice, however, that these are the same budget constraints as in the PAYG model, once we under-

\footnotetext{
14 This idea is not restricted to the particular strategy explored in Conesa and Garriga (2008); the term "recognition bond" has been used elsewhere, including by Feldstein and Liebman (2002). Diamond (1996) also highlights this example from the experience of Chile in 1981
} 
stand that (i) the transfer collected by workers is equal to debt issued $t r_{T}=b_{T+1}$ and (ii) principal and interest on the debt (or the recognition bonds) are equal to the pensions $\left(1+r_{T+1}\right) b_{T+1}=p_{T+1}$.

In the next period, the total amount of the recognition bonds (or government bonds to pay for the transfer) must be paid with interest. By construction, though, this quantity is exactly equal to the amount of the pensions, so the new generation of workers born in period $T+1$ must pay taxes and again be compensated by a transfer in the exact manner as the previous generation, and so on until infinity.

The introduction of recognition bonds does not increase the level of debt for our model's government; rather it makes the debt explicit. Pakko (2009) provides a brief overview of the U.S. federal deficit and explains the distinction between "on-budget" and "off-budget" items. Social Security is an off-budget item and is reported only as part of the unified budget. Currently, the Social Security Trust Fund in the United States is counted as a surplus since tax receipts are larger than benefit payments. This surplus appears in reported figures of the combined budget. For example, in 2008 the official measure reported by the government- the unified budget deficitwas $\$ 455$ billion. The on-budget deficit was $\$ 638$ billion, with an off-budget surplus of $\$ 183$ billion, funded primarily from Social Security. Pakko (2009) questions which deficit measureon-budget or unified budget-the government will report starting in 2017 when Social Security outlays exceed revenues. The implicit debt guarantee to future generations is currently not reported, even though it is politically unlikely that the federal government will default on these future obligations.

Chile approached a similar transition in 1981 by incurring no debt; instead, they began building a fiscal surplus three years before the reform started. Chilean GDP grew at an average of 8 percent per year during this period, and the high growth fueled increased tax revenue. Diamond (1996) states that "it may be that a surplus is a contributing condition for a successful privatization” (p. 80). Valdés-Prieto (1998) acknowledges that a surplus is sufficient, but not a necessary condition, to reform. During a review of the reforms in several Latin American countries in the early and mid-1990s, he finds that even countries emerging from hyperinflation have successfully managed a transition by issuing debt after the inflationary period.

\section{Welfare-Improving Transition: No-Default and Lower Labor Distortions}

We now use the intuition and fiscal policy approach from Conesa and Garriga (2008, 2009) to present the case in which a switch to an FF defined-contribution model can be welfare improving. The existing literature has shown that in a dynamically efficient economy, it is not possible to raise aggregate welfare by redistributing resources across generations (a result that goes back to Diamond, 1965), which is basically our approach in the previous reform scenarios. The first two scenarios were situations in which one cohort might benefit at the expense of others; the last one was a Pareto-neutral privatization (nobody won or lost; we simply made the implicit debt explicit). However, if the economy is inefficient because of distortions, then we can increase aggregate welfare by removing the distortions.

Furthermore, we have seen that in the case of a decline in the labor force (or a corresponding increase in the dependency ratio), the two policy options are increasing the payroll tax or cutting benefits. Increasing the payroll tax worsens the distortion on labor.

In the baseline scenario the distortion in the economy comes from the tax on labor, which is used to finance the PAYG system. Pensions are viewed as a pure transfer, while contributions are viewed as a pure tax. Notice that actual pension systems do have some connection between labor income and pension entitlements so that, in reality, individuals may realize the link between their individual contributions and their pension entitlements, thus reducing the distortion. However, insofar as the connection between contributions and pensions is not one to one (because of redistributive considerations usually present in most systems), there will still be a distortion. 
Another way to view the distortion is by looking at the equivalent economy in which the implicit liabilities of the PAYG system have been made explicit. From equation (18), we see that workers are paying taxes as a function of their labor income, $\tau_{T} w_{T} \ell_{T}$, and at the same time they are receiving a compensatory transfer, $t_{T}$, independent of their labor supply decisions. Basic economic principles imply a deadweight loss because of this scheme. Moreover, this distortion would increase in the labor supply elasticity. Reducing both the tax and the transfer would result in an efficiency gain.

Most countries have additional distortions that are important in studying social security reforms. For example, mandatory retirement rules could be eliminated during a reform, as suggested by Conesa and Garriga (2003). Without this restriction, the transition to an $\mathrm{FF}$ system requires a lower level of compensating transfers and ensures a faster convergence to the new steady state. In addition, the government can change the tax treatment of capital income of retirees as an alternative compensation mechanism. In considering these different distortions, the relevant set of budget constraints becomes

$$
\begin{aligned}
& c_{1, T}+a_{T+1}+b_{T+1} \leq w_{T} \ell_{T}-\tau_{1, T} w_{T} \ell_{T}+t_{T} \\
& C_{2, T+1} \leq\left(1-\tau_{2, T+1}\right) w_{T+1} \ell_{T+1}\left(1+r_{T+1}\left(1-\theta_{T+1}\right)\right) a_{T+1} \\
& +\left(1+r_{T+1}\right) b_{T+1} .
\end{aligned}
$$

In addition to the implicit debt of the social security system, a larger set of distortions has been made explicit. Distortions on labor income of the young are now denoted by $\tau_{1, T}$, while the distortion on labor income of the old is $\tau_{2, T+1}$ (with compulsory retirement this is equal to 100 percent), and $\theta_{T+1}$ denotes distortions on investment decisions.

Given this scenario, it is possible for a government to reduce the distortions and generate welfare improvements, implying a lower level of compensatory transfers or a lower level of recognition bonds. Such a strategy is illustrated in Conesa and Garriga (2008, 2009). They show that the optimal social security reform consists of providing compensatory transfers to the initial old generation (transfers almost as large as their social security entitlements) financed with debt and lowering labor income taxes on impact to increase them later.

The introduction of capital income taxes in the analysis allows for the generation of additional welfare gains since it drastically reduces the need for compensatory transfers for the initial generations alive. On average, capital income taxes translate into very large subsidies, especially for the oldest cohorts. Effectively, changing the fiscal treatment of capital income can become a close substitute for compensatory lump-sum transfers to the initial old generation.

\section{CONCLUSION AND POLICY IMPLICATIONS}

We have examined some of the "myths" surrounding social security as presented by Orsagz and Stiglitz (1999), particularly by focusing on comparing the transition between systems as opposed to tabula rasa comparisons between a PAYG and an FF system. We have presented the findings of other researchers who have documented the welfare gain under an FF definedcontribution system without considering the welfare cost for the transition generation. We build on the notion that a PAYG social security system is just an implicit liability for the tax authority, and as such it could be converted into an explicit liability (i.e., government debt) without cost. After such conversion the government can focus on designing reforms without inevitably generating welfare losses for some generations. The key insight is that this scenario is possible only if the distortions (introduced either by the financing of social security or other types) are reduced.

Hence, the focus should be shifted from the nature of the social security system itself and the debate centered instead on the distortions introduced by all tax-transfer schemes currently present in the economy. The debate on social security reform then becomes a debate on how to allocate to different cohorts the efficiency gains generated by the reduction of these distortions. 


\section{REFERENCES}

Auerbach, Alan J. and Kotlikoff, Laurence J. "Evaluating Fiscal Policy with a Dynamic Simulation Model." American Economic Review, May 1987, 77(2), pp. 49-55.

Bateman, Hazel and Piggott, John. "Mandatory Retirement Saving in Australia." Annals of Public and Cooperative Economics, December 1998, 69(4), pp. 547-69.

Birkeland, Kathryn and Prescott, Edward C. “On the Needed Quantity of Government Debt.” Federal Reserve Bank of Minneapolis Quarterly Review, November 2007, 31(1), pp. 2-15; www.minneapolisfed.org/research/QR/QR3111.pdf.

Board of Trustees, Federal Old-Age and Survivors Insurance and Federal Disability Insurance Trust Funds. The 2009 Annual Report of the Board of Trustees of the Federal Old-Age and Survivors Insurance and Federal Disability Insurance Trust Funds. Washington, DC: U.S. Government Printing Office, 2009; www.socialsecurity.gov/OACT/TR/2009/.

Butelmann, Andrea and Gallego, Francisco. "Household Savings in Chile: Microeconomic Evidence.” Working Paper No. 63, Central Bank of Chile, February 2000.

Conesa, Juan C. and Garriga, Carlos. “The Status Quo Problem in Social Security Reforms.” Macroeconomic Dynamics, November 2003, 7(6), pp. 691-710.

Conesa, Juan C. and Garriga, Carlos. "Optimal Fiscal Policy in the Design of Social Security Reforms.” International Economic Review, February 2008, 49(1), pp. 291-318.

Conesa, Juan C. and Garriga, Carlos. "Optimal Response to a Transitory Demographic Shock in Social Security Financing," in Robert Fenge, Georges de Ménil, and Pierre Pestieau, eds., Pension Strategies in Europe and the United States. Cambridge, MA: MIT Press, pp. 98-113. Reprinted in Federal Reserve Bank of St. Louis Review, January/February 2009, 91(1), pp. 33-48; http://research.stlouisfed.org/publications/review/09/01/Conesa.pdf.

Conesa, Juan C. and Krueger, Dirk. "Social Security Reform with Heterogeneous Agents." Review of Economic Dynamics, October 1999, 2(4), pp. 757-95.

Coronado, Julia Lynn. "The Effects of Social Security Privatization on Household Saving: Evidence from the Chilean Experience.” Contributions to Economic Analysis and Policy, 2002, 1(1), Article 7, pp. 152-75.

Diamond, Peter A. "National Debt in a Neoclassical Growth Model." American Economic Review, December 1965, 55(5 Part 1), pp. 1126-50.

Diamond, Peter A. "Proposals to Restructure Social Security." Journal of Economic Perspectives, Summer 1996, 10(3), pp. 67-88.

Diamond, Peter A. "Social Security.” American Economic Review, March 2004, 94(1), pp. 1-24.

Disney, Richard; Emmerson, Carl and Smith, Sarah. "Pension Reform and Economic Performance in Britain in the 1980s and 1990s." NBER Working Paper, No. 9556, National Bureau of Economic Research, March 2003; www.nber.org/papers/w9556.pdf?new window=1. 


\section{Aubuchon, Conesa, Garriga}

Drucker, Peter F. and Munnell, Alicia H. "The Financial Crisis and Restoring Retirement Security.” Testimony before the Committee on Education and Labor. U.S. House of Representatives, February 24, 2009; http://edlabor.house.gov/documents/111/pdf/testimony/20090224AliciaMunnellTestimony.pdf.

Federal Reserve Board. 2007 Survey of Consumer Finances. www.federalreserve.gov/pubs/oss/oss2/2007/scf2007home.html.

Feldstein, Martin. “Would Privatizing Social Security Raise Economic Welfare?” NBER Working Paper No. 5281, National Bureau of Economic Research, September 1995; www.nber.org/papers/w5281.

Feldstein, Martin. Privatizing Social Security. Chicago: University of Chicago Press, 1998.

Feldstein, Martin and Liebman, Jeffrey B. "Social Security,” in Alan J. Auerbach and Martin Feldstein, eds., Handbook of Public Economics. Volume 4, Part 6. Amsterdam: Elsevier Science, 2002, pp. 2245-324.

Gramlich, Edward M. "Mending But Not Ending Social Security: The Individual Accounts Plan.” Federal Reserve Bank of St. Louis Review, March/April 1998, 80(2), pp. 7-10; http://research.stlouisfed.org/publications/review/98/03/9803eg.pdf.

Granville, Brigitte and Mallick, Sushanta. "Does Capital Market Reform Boost Savings? Evidence from the UK Pension Reforms.” Working paper, Royal Institute of International Affairs, December 2002; www.chathamhouse.org.uk/files/3065 pension.pdf.

Hepp, Stefan. "Mandatory Occupational Pension Schemes in Switzerland: The First Ten Years." Annals of Public and Cooperative Economics, December 1998, 69(4), pp. 533-45.

Huang, He; Selahattin, Imrohoroglu and Sargent, Thomas J. "Two Computations to Fund Social Security." Macroeconomic Dynamics, January 1997, 1(1), pp. 7-44.

Jeske, Karsten. "Pension Systems and Aggregate Shocks." Federal Reserve Bank of Atlanta Economic Review, First Quarter 2003, 88(1), pp. 15-31; www.frbatlanta.org/filelegacydocs/erq103 jeske.pdf.

Johnson, Paul. "The Reform of Pensions in the UK." Annals of Public and Cooperative Economics, December 1998, 69(4), pp. 517-32.

Johnson, Paul and Stears, Gary. "Should the Basic State Pension Be a Contributory Benefit?" Fiscal Studies, February 1996, 17(1), pp. 105-12.

Kotlikoff, Laurence J. "Privatizing U.S. Social Security: Some Possible Effects on Inter-generational Equity and the Economy.” Federal Reserve Bank of St. Louis Review, March/April 1998, 80(2), pp. 31-37; http://research.stlouisfed.org/publications/review/98/03/9803lk2.pdf.

Orszag, Peter R. and Stiglitz, Joseph E. "Rethinking Pension Reform: Ten Myths About Social Security Systems." Presented at the World Bank Conference, "New Ideas About Old Age Security," September 14-15, 1999; www.iza.org/de/calls conferences/pensionref pdf/panel stiglitz.pdf.

Pakko, Michael. "Deficits, Debt and Looming Disaster: Reform of Entitlement Programs May Be the Only Hope.” Federal Reserve Bank of St. Louis Regional Economist, January 2009, pp. 4-9; http://stlouisfed.org/publications/re/2009/a/pdf/debts.pdf.

Pecchenino, Rowena A. and Pollard, Patricia S. "Reforming Social Security: A Welfare Analysis.” Federal Reserve Bank of St. Louis Review, March/April 1998, 80(2), pp. 19-30. 
Samuelson, Paul A. "An Exact Consumption-Loan Model of Interest with or without the Social Contrivance of Money." Journal of Political Economy, December 1958, 66(6), pp. 467-82.

Samuelson, Paul A. "Optimal Social Security in a Life-Cycle Growth Model.” International Economic Review, October 1975, 16, pp. 539-44.

Social Security Administration. “The Future of Social Security.” SSA Publication No. 05-10055, 2008.

Sundén, Annika. "The Swedish NDC Pension Reform.” Annals of Public and Cooperative Economics, December 1998, 69(4), pp. 571-83.

Rangel, Antonio. "Forward and Backward Intergenerational Goods: Why Is Social Security Good for the Environment?” American Economic Review, June 2003, 93(3), pp. 813-34.

Social Security and Medicare Boards of Trustees. "Status of the Social Security and Medicare Programs." Social Security Administration Actuarial Publications, 2010; www.ssa.gov/OACT/TRSUM/index.html.

Valdés-Prieto, Salvador. “The Latin American Experience with Pension Reform.” Annals of Public and Cooperative Economics, December 1998, 69(4), pp. 483-516.

World Bank. Averting the Old Age Crisis: Policies to Protect the Old and Promote Growth. New York: Oxford University Press, 1994; www-wds.worldbank.org/external/default/WDSContentServer/WDSP/IB/1994/09/01/ $0000092653970311123336 /$ Rendered/PDF/multi page.pdf. 
